ELORE (ISSN 1456-3010), vol. $18-2 / 2011$.

Julkaisija: Suomen Kansantietouden Tutkijain Seura ry.

[http://www.elore.fi/arkisto/2_11/saarinen.pdf]

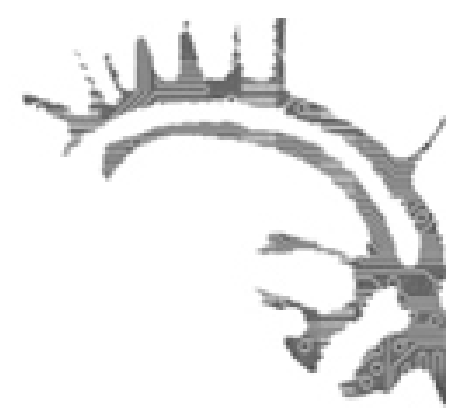

KIRJA-ARVIO

\title{
IMAAMI PYÖRTYI JA MUITA MAKUJA ISLAMIN MAILTA
}

HALLENBERG, HELENA \& PERHO, IRMELI 2011: Ruokakulttuuri islamin maissa. Helsinki: Gaudeamus. 479 sivua.

\section{Tuija Saarinen}

Ruokakulttuuri islamin maissa esittelee ruoka- ja nautintoaineiden kulttuurihistoriaa Lähi-idässä ja muissa islamin vaikutuspiirin maissa. Se tarkastelee myös Koraanin ja muiden islamin peruslähteiden ruokaa koskevia ohjeita.

Tänä päivänä muslimeja elää kaikkialla maailmassa. Islam onkin maailman toiseksi suurin ja nopeimmin kasvava uskonto. Muslimeja arvioidaan nykyisin olevan noin miljardi. Varsinainen alueellisesti yhtenäinen islamilainen maailma ulottuu Afrikan länsirannikolta Indonesiaan ja Keski-Aasiasta Saharan eteläpuolelle. Euroopassa muslimeja on noin 20 miljoonaa, Suomessa vuoden 2010 arvion mukaan reilut 40000.

\section{SIKA - UHRIELÄIN VAI EPÄPUHDAS?}

On selvää, että näin laajalle alueelle levittäytyneen uskonnon tunnustajien ruokakulttuurissa on jo erojakin. Maailman kaikkia muslimeja yhdistävät islamin ruokailua koskevat ohjeet. Tunnetuin niistä on kielto syödä verta ja sikaa sekä nauttia alkoholia. Islam antaa myös ohjeita ja määräyksiä oikeasta teurastustavasta. Muslimien halalteurastus ja juutalaisten kosher-teurastus tehdään samalla tavalla: elävän eläimen kaula leikataan poikki ja ruho käännetään ylösalaisin, jotta veri valuu mahdollisimman pian pois. Suomen laki edellyttää, että eläin on ennen islamilaista tai juutalaista teurastusta tainnutettava.

Muslimien on sallittua tarvittaessa syödä sekä juutalaisten että kristittyjen kanssa, kuin myös heidän teurastamaansa lihaa, kunhan pidättäydytään kielletyistä ruoka- 
Tuija Saarinen: Imaami pyörtyi ja muita makuja islamin mailta

aineista. Tämä mahdollistaa osallistumisen esimerkiksi koulu- tai työpaikkaruokailuun, jossa rituaalisesti teurastettua lihaa ei aina voida tarjota. Käytännössä teurastussäännöstä joudutaankin joustamaan, ja useimmat Suomen muslimit ostavat lihansa tavallisesta marketista. Tiukimmin uskonnon määräyksiä noudattavat pidättäytyvät sen sijaan vain rituaaliteurastetuissa tuotteissa tai kasvisruuassa.

Verensyöntikielto perustuu seemiläisten kansojen käsitykseen siitä, että sielu asuu veressä - heittäväthän niin ihminen kuin eläin henkensä veren valuessa ruumiista. Siksi veren nauttiminen ravinnoksi on kauhistus. Teurastuksen yhteydessä valuvaa verta pidetään myös likaisena, eikä sitä hyödynnetä missään muodossa. Nykyisin veren karttamista perustellaan sillä, että siinä saattaa olla bakteereja.

Mitä löytyykään siansyöntikiellon taustalta? Sika kesytettiin kotieläimeksi Anatoliassa, Lähi-idässä ja Kiinassa samoihin aikoihin. Ensimmäinen kotisiaksi tunnistettu luulöytö on noin 9000-luvulta eaa. - siis kauan ennen islamin syntyä. Juutalaisten ja muslimien sikatabuissa on luultavasti mukana Lähi-idän ja Egyptin muinaiskulttuurien käsityksiä sian ainakin osittaisesta pyhyydestä - Lähi-idän muinaiskansat käyttivät sikaa uhrieläimenä, parannusriiteissä ja magiassa. Nyky-muslimille ainoa ja riittävä peruste sianlihan syömättömyyteen on se, että Jumala on sen kieltänyt Koraanissa. Muslimien ja juutalaisten hygieeniset selitykset puolestaan korostavat, että sianliha pilaantuu erityisen herkästi ja sen säilyttäminen on hankalaa kuumassa ilmastossa tai että siassa viihtyvät loiset. Kuitenkaan tieto bakteerien olemassaolosta ei ole yhtä vanha kuin sianlihansyöntikielto.

Äärimmäisimmän tulkinnan mukaan kaikki sikaan liittyvä on likaista. Tarkka muslimi ei käytä siannahkakenkiä tai -takkia eikä sianharjaksista tehtyä partasutia. Toiset puolestaan eivät edes tarkista, onko lääkkeiden osana käytetty sikaperäistä liivatetta, mutta hartaimmat kieltäytyvät niistäkin. Tunnollisimmat perehtyvät e-koodeihin ja varmistavat, etteivät esimerkiksi makeiset tai jäätelö sisällä sikaperäistä liivatetta tai emulgointiainetta. Sian sisältymistä suomalaiskauppojen myymiin ruokatarvikkeisiin ei pysty aukottomasti poissulkemaan edes e-koodeja ulkoa opettelemalla, sillä tuoteselosteissa voidaan mainita vain "sisältää eläinrasvaa".

On mielenkiintoista pohtia islamilaisen ja suomalaisen kulttuurin sikasuhdetta, sillä sika ei suinkaan ole neutraali eläin "koivun ja tähdenkään" alla. Sika on tärkeä tuotantoeläin, jonka lihan riittävyys on ollut elintason symboli. Oma kulttuurimme suhtautuu sikaan ristiriitaisesti, sillä pidämme muslimien lailla sikaa epäsiistinä olentona ja sikaa käypänä haukkumanimenä. Samalla sialla on hellyttävämpiäkin ilmentymiä kuten satujen pikku porsaat ja moninaiset nasu-hahmot ja panemme päiväkotilapset vakuuttamaan kuorossa: "Porsaita äidin oomme kaikki". Kaduilla betoniporsaat varmistavat turvallisuuttamme siellä, missä hurjastelijat muutoin vaarantaisivat kulkumme. Sialla onkin yllättäen suojelusenkelin funktio.

\section{Alkoholi estäÄ AJATtelemasta oIKeIN}

Kunnon muslimi ei nauti alkoholia. Alkoholin nauttimiskielto yhdistää kaikkia muslimeja, vaikka käytäntö vaihtelee maasta toiseen. Esimerkiksi liberaalissa Turkissa 
Tuija Saarinen: Imaami pyörtyi ja muita makuja islamin mailta

alkoholin nauttiminen on suhteellisen vapaata, toisin kuin Saudi-Arabiassa, jossa se on täysin kiellettyä. Tiedetään, että profeetta Muhammed joi arabien perinteistä, vedessä liotetuista rusinoista valmistettua käynyttä juomaa. Alkoholin kieltäminen pohjautuu profeetan kokemaan ihmeelliseen yölliseen matkaan, jolla hän sïrtyi Mekasta Jerusalemiin ja sieltä edelleen taivaaseen. Jerusalemissa hänelle tarjottiin muiden profeettojen läsnä ollessa kolme maljaa, joissa oli vettä, maitoa ja viiniä. Profeetta valitsi maidon, jottei "hänen kansakuntansa hukkuisi tai joutuisi harhaan". Myöhemmin profeetta sai viiniä koskevia ilmestyksiä, joissa hän vakuuttui, että viini on Saatanan työtä.

Nykymuslimi kieltäytyy kaikista alkoholin muodoista. Tärkein syy on alkoholin vaikutus aivoihin. Se estää ihmistä ajattelemasta oikein ja pohtimasta Jumalaa. Pienikin määrä päihdyttävää ainetta on haitallista, sillä "jos ämpärillinen juovuttaa, siemaisukin on kielletty”. Käytännössä muiden uskontojen edustajien kanssa rinnakkain elettäessä on vaikea varoa pieniä siemauksia. Alkoholi voi sisältyä ainesosana täytesuklaaseen, energiajuomaan tai yskänlääkkeeseen, eikä kielitaito aina riitä tuoteselosteiden selvittämiseen. Tulkinnat alkoholin haitallisuudestakin vaihtelevat perheestä ja maasta toiseen. Erään ohjeen mukaan muslimi voi nauttia energiajuomaa, joka sisältää alle 0,5 tilavuusprosenttia alkoholia. Tunnollisimmat tarkistavat myös kosmeettisten ja hygieniatuotteiden sisällön eivätkä käytä alkoholia antiseptisenä aineenakaan.

Islamin julkisuuskuvassa korostuvat erilaiset kiellot. Onkin syytä painottaa, että pohjimmiltaan islam on salliva uskonto, joka ottaa huomioon erilaiset poikkeustilanteet. Muslimit ovat yksimielisiä siitä, että ihmiselämä on tärkeämpää kuin erilaiset määräykset. Jos ihminen on kuolemassa nälkään, eikä muuta ravintoa ole saatavilla, hänen on lupa syödä myös kiellettyjä eläimiä "säilyttääkseen elämän, ei tullakseen kylläiseksi”. Ei myöskään ole synti, jos tietämättään tai pakon edessä syö jotain kiellettyä, sillä "Jumala on anteeksiantava, armelias." Myös sairaana ollessa on tarpeen käyttää sopivaa lääkettä. Alkoholia ja siasta saatavia osia voi käyttää lääkkeenä, kun muita keinoja ei ole. Esimerkiksi Saudi-Arabiassa sallitaan alkoholeihin luokiteltavat makeutusaineet sorbitoli ja ksylitoli diabeteksen hoidossa, vaikka ne ovat muutoin kiellettyjä.

\section{Arabialainen vieraanvaraisuUs}

Kieltojulkisuudessa unohtuu usein myös vanhaan arabialaiseen paimentolaiskulttuuriin ja sieltä islamiin hyveeksi välittynyt vieraanvaraisuus. Kestitystä saaneen edellytettiin vastavuoroisesti kestitsevän muita. Ruuan tarjoaminen onkin yleismaailmallinen tapa lujittaa ihmisten välisiä siteitä ja sinetöidä sopimuksia. Vieraanvaraisuus ja ihmissuhteet ovat tärkeitä ja suhdeverkostoa pidetään yllä tarjoamalla oikeanlaista ruokaa oikealla tavalla oikeille ihmisille. Vieraiden runsas ja ylenpalttinen kestitseminen nostaa isännän statusta. Vieraille tarjotaan aina jotain, vähintäänkin esimerkiksi vettä, mehua, kahvia tai teetä, mutta vierasta taivutellaan jäämään aterialle.

Kahvi on yksi niistä arabialais-islamilaisen ruokakulttuurin piirteistä, jotka ovat rantautuneet ja juurtuneet pohjolaan niin olennaisiksi ruokakulttuurin osiksi, ettei keskivertokansalainen osaa ajatellakaan jakavansa arabialaista perinnettä. Kahvin 
Tuija Saarinen: Imaami pyörtyi ja muita makuja islamin mailta

alkuperä on Etiopiassa, josta kahvipensas tuli viimeistään 1400-luvulla Arabian niemimaan eteläosiin Jemeniin. Kahvijuoman synnystä on erilaisia tarinoita. Historiallisten lähteiden perusteella tiedetään, että islamin alueilla sitä nauttivat aluksi Jemenin suufimystikot, joiden tuli pysytellä yöllä hereillä.

Kahvi levisi tehokkaasti suufien mukana, jotka edustivat kaikkia yhteiskuntaluokkia ja kulkivat kauppamatkoillaan muihin maihin. 1500-luvun lopun eurooppalaisesta lähteestä löytyy ensimmäinen maininta kahvista, ja seuraavalla vuosisadalla alkoi sen voittokulku eurooppalaiseen maailmaan. Nykyisin kahvilainstituutio kukoistaa islamilaisessa kulttuurissa. Kahvilat ovat osa maiden elämäntapaa, ja ne ovat esimerkiksi ramadanin aikaan täynnä öisinkin. Miehillä on usein kantakahvila, jossa he seurustelevat keskenään. Näin on myös Suomessa, jossa suurimmissa kaupungeissa tiettyihin kahviloihin kokoontuu tiettyjen kansallisuuksien edustajia. Naisten kahvinjuonti puolestaan on kotoista kulttuuria.

Yhteistä perusislamilaista kahvia ei kuitenkaan ole olemassakaan, vaan kahvista valmistettavat juomat vaihtelevat maittain. Keskivertosuomalaisen juoma, vaaleapaahtoinen suodatinkahvi, on arabialaisen tai turkkilaisen kahvin laimennettu muunnelma. Arabialainen kahvijauhe on tummapaahtoista ja erittäin hienoksi jauhettua. Kahvi keitetään pienessä, kahvalla varustetussa pannussa siten, että kahvijauhe ja sokeri sekoitetaan kylmään veteen. Seos kiehautetaan, hämmennetään ja kiehautetaan uudelleen. Valmis kahvi kaadetaan pienen pieniin kuppeihin, joiden pohjalle sakan annetaan laskeutua. Siksi kahvia ei hämmennetä. Islamilaisiin kahvihetkiin ei kuulu suomalaistapainen painostava hiljaisuus, jota vain lusikan kilinä posliinikupin reunoja vastaan säestää, vaan iloinen puheensorina.

\section{IMAAMI PYÖRTYI JA MUITA RUOKAOHJEITA}

Ruokakulttuuri islamin maissa sisältää lukijan iloksi myös ruokaohjeita, joiden osuus liki viidestä sadasta sivusta on vajaa neljännes. Reseptit on valittu islamin ydinalueilta Lähi-idästä, Iranista ja Turkista. Osa ruuista on tuttuja myös muualta - ainakin hieman muunnellussa muodossa. Esimerkiksi appelsiinisalaattia syödään Välimeren länsilaidankin maissa, seesami- ja munakoisotahnat ovat tuttuja kaikille Kreikan kävijöille. Kasvisten käyttö on huomattavan runsasta ja reseptien toteuttaminen suhteellisen helppoa nyky-Suomessa. Ainoa ongelma lienevät tuoreet yrtit, joita käytetään lähinnä nipuittain. Yrttien saatavuus mistä tahansa lähikaupasta ei ole taattua. Niiden laadussa on usein toivomisen varaa ja hinta hirvittävä. Intohimoinen Välimeren itäosan ruokien ystävä kasvattaakin itse omat yrttinsä.

Monet ruokaohjeista olivat itselleni tuttuja entuudestaan joko matkoilta tai tutkimusmatkoilta omasta keittiöstä. On muistettava, että perinneruokia tehdään monella tapaa ja ohjeet vaihtelevat keittokirjan kirjoittajankin mukaan. Ainesosien suhteet voivat kasvisruuissa vaihdella huomattavastikin aina kokin maun mukaan, eikä mausteita tarvitse mitata pikkutarkasti. Esimerkiksi iki-ihana munakoisoruoka Imaami pyörtyi (Imam bayildi) on omana toteutuksenani vieläkin tainnuttavampi kuin Hallenbergin ja Perhon ohjeilla valmistettu. Joka epäilee, ettei kasvisruuasta tule täyteen, ei ole 
maistanut pyörtyvän imaamin lempiruokaa.

Ruokakulttuuri on mielenkiintoinen kulttuurin osa ja keino ilmentää omaa identiteettiä - niin kristinuskoon perustuvaa suomalaisuutta kuin islamilaisuutta. Ruokakulttuuri islamin maissa -teoksella on kunniahimoinen lähestymistapa, sillä se tarkastelee ruokakulttuuria uskonnon ja kulttuurihistorian näkökulmista ottaen huomioon paikallisia erikoispiirteitä ja muiden kulttuurien vaikutusta. Toteutus on moniulotteinen.

Lukisin tulevaisuudessa kernaasti tutkimuksen myös siitä, miten nykyisessä monikulttuurisessa Suomessa kukin ylläpitää omaa ruokakulttuuriaan ja millaisia vaikutteita eri ruokaperinteet toisilleen antavat. Oma kotoinen ruokakulttuurimme on muuttunut viimeisten vuosikymmenten aikana. Olemme omaksuneet uusia raaka-aineita ja ryhtyneet valmistamaan ruokalajeja, joista esimerkiksi isovanhempamme eivät olleet kuulleetkaan. Ruuan fuusioituminen onkin mielenkiintoinen ilmiö ja kulttuurien rinnakkaiselo hedelmällinen tilanne, jossa lohikeitto vaihtuu pyörtyneeksi imaamiksi.

Monien tässä esittelemättä jäävien ulottuvuuksiensa ohella teos tarjoaa myös näkymiä islamilaiseen estetiikkaan. Teos onkin ehdottomasti kaunein pitkään aikaan näkemäni kirja, taitettu ja kuvitettu viimeistä yksityiskohtaa myöten edustamaan taustakulttuuriaan. Mattapintaiselle, kellertävälle paperille painettua tekstiä on nautinnollista lukea, mikä ei ole vähäpätöinen seikka ottaen huomioon kirjan monet funktiot. Kulttuurintutkija saa teoksesta paljon irti moniin eri tarkoituksiin - niin islamin perusteiden, erityispiirteiden kuin puhtaan ruokaperinteenkin näkökulmista. Epäilemättä kirjasta tulee alansa klassikko.

Filosofian tohtori Tuija Saarinen on hiljattain julkaissut teoksen suomalaisen kahvinjuonnin kulttuurihistoriasta. 